\title{
Yüksek Verimli ve Uzun Dönem Kararlı Perovskit Güneș Hücrelerinin Üretimi için Perovskit/Spiro-OMeTAD Arayüzeyinin Thiol Molekülleri ile Modifikasyonu
}

\author{
Seçkin Akın ${ }^{1 *}$ \\ ${ }^{1}$ Karamanoğlu Mehmetbey Üniversitesi, Mühendislik Fakültesi, Metalurji ve Malzeme Mühendisliği Bölümü, Karaman, Türkiye (ORCID: 0000-0001-9852-7246)
}

(İlk Geliş Tarihi 1 Ekim 2019 ve Kabul Tarihi 10 Kasım 2019)

(DOI: 10.31590 /ejosat.640344)

ATIF/REFERENCE: Akın, S. (2019). Yüksek Verimli ve Uzun Dönem Kararlı Perovskit Güneş Hücrelerinin Üretimi için Perovskit/Spiro-OMeTAD Arayüzeyinin Thiol Molekülleri ile Modifikasyonu. Avrupa Bilim ve Teknoloji Dergisi, (17), 727-735.

\begin{abstract}
$\ddot{O} \mathbf{z}$
Perovskit malzemesinin yüzey/sınır kusurları içeren yüzey morfolojisi, yüksek nem hassasiyeti ve operasyonel koşullarda hücre içine doğru meydana gelen iyon göçü perovskit güneş hücrelerinin çözüm bekleyen en önemli problemleri arasındadır. Arayüzey mühendisliği, perovskit güneş hücrelerinde bu tür sorunlara karşı kullanılan en etkili yöntemlerden biridir. Bu çalışmada, thiol türevi 1phenyl-1H-tetrazole-5-thiol (PT(thiol)) moleküllerinin, perovskit/spiro-OMeTAD arasında arayüzey tabakası olarak kullanıldığı hücrelerinin üretimi gerçekleştirilmiştir. Arayüzey tabakasının kullanıldığı hücrelerin açık devre gerilim ( $\left.\mathrm{V}_{\mathrm{OC}}\right)$ değerlerinde $40 \mathrm{mV}$ iyileşme sağlanarak \%19.5 verim elde edilmiştir. Fotovoltaik performanstaki bu iyileşme perovskit tabakasının yüzeyindeki ve tane sınırlarındaki rekombinasyon merkezlerinin pasivasyonu ile açıklanırken; arayüzey tabakasının operasyonel kararlılık problemine ciddi bir katkı sağladığı da tespit edilmiştir. Sürekli ışınım altında ve \%40 nem içeren bir ortamda gerçekleştirilen kararlılık test sonucunda arayüzey tabakalı hücrenin 300 saat sonunda başlangıç veriminin \%75'ini koruduğu tespit edilmiştir. Sonuç olarak PT(thiol) moleküllerinin perovskit hücrelerin en önemli sorunlarından biri olan kararlılık problemine çözüm sunma potansiyeli olduğu; aynı zamanda yüzey özelliklerini de iyileştirerek hücre performansını arttırdığı tespit edilmiştir.
\end{abstract}

\section{Modification of Perovskite/Spiro-OMeTAD Interface with Thiol Molecules for the Fabrication of Highly Efficient and Long-Term Stable Perovskite Solar Cells}

\begin{abstract}
The surface morphology of the perovskite material with surface / boundary defects, high sensitivity to humidity, and ion migration into the cell under operational conditions are among the most important problems of perovskite solar cells. Interfacial engineering is one of the most effective methods against to such problems in perovskite solar cells. In this study, the cells in which thiol derivative 1-phenyl1H-tetrazole-5-thiol (PT(thiol)) molecules were used as an interfacial layer between perovskite / spiro-OMeTAD have been fabricated. The open circuit voltage $\left(\mathrm{V}_{\mathrm{OC}}\right)$ values of the cells using the interface layer were improved by $40 \mathrm{mV}$ and the efficiency of $19.5 \%$ was obtained. This improvement in photovoltaic performance is explained by the passivation of recombination centers on the surface of the
\end{abstract}

\footnotetext{
* Sorumlu Yazar: Karamanoğlu Mehmetbey Üniversitesi, Mühendislik Fakültesi, Metalurji ve Malzeme Mühendisliği Bölümü, Karaman, Türkiye, ORCID: 0000-0001-9852-7246, seckinakin@kmu.edu.tr 
perovskite layer and at the grain boundaries; it is also determined that the interface layer contributes to the problem of operational stability. Stability test performing under continuous illumination and $40 \%$ relative humidity displayed that the cell including interlayer maintained $75 \%$ of its initial efficiency after 300 hours. As a result, PT(thiol) molecules have the potential to provide solution to the stability problem, which is one of the most important problems of perovskite cells; it has also been found to improve cell performance by improving surface properties.

Keywords: Perovskite solar cells, Interfacial modification, 1-phenyl-1H-tetrazole-5-thiol, Cell stability.

\section{Giriş}

On yıldan kısa bir sürede \%25.2 gibi yüksek bir verim değerine ulaşan organik-inorganik perovskit güneş hücrelerinin fotovoltaik piyasasında söz sahibi silikon hücrelere en iyi alternatif olduğu söylenebilir ("National Renewable Energy Laboratory (NREL)," 2019). Yüksek verim ve kolay üretim süreçlerine rağmen perovskit hücrelerin ticarileşememesinin önündeki en büyük engellerden biri şüphesiz hücre mimarisinde boşluk transfer tabakası (hole transport layer, HTL) olarak kullanılan 2,2',7,7'- tetrakis(N,N-di-pmethoxyphenylamine)-9-9'-spirobifluorene (spiro-OMeTAD) malzemesinden kaynaklanmaktadır (Akin, Liu, ve ark., 2018; Ameen ve ark., 2016; Arora ve ark., 2017; Kim ve ark., 2019). Hücre mimarisinde perovskit tabakasından gelen boşlukların metal üst elektrota etkin bir şekilde iletilmesinden sorumlu olan spiro-OMeTAD malzemesi katkısız halde oldukça düşük bir iletkenlik $\left(\approx 10^{-5} \mathrm{~S} \mathrm{~cm}^{-2}\right)$ ve boşluk mobilitesi $\left(\approx 10^{-4} \mathrm{~cm}^{2} \mathrm{~V}^{-1} \mathrm{~s}^{-1}\right)$ sunmaktadır (Seo ve ark., 2018). Yük transferini ve dolayısıyla hücre performansını olumsuz yönde etkileyen bu durum spiro-OMeTAD malzemesinin lithium bis(trifluoromethanesulfonyl)-imide (Li-TFSI), cobalt(III) bis(trifluoromethanesulfonyl)-imide (FK-209) ve 4-tertbutyl pyridine (tBP) gibi katk1 malzemeleri ile katkılanma ihtiyacı doğurmaktadır. Mevcut katkı malzemeleri spiro-OMeTAD malzemesinin hızlı bir şekilde oksitlenerek daha iyi elektriksel parametreler sunmasını sağlarken perovskit malzemesinin uzun dönem kararlılığını da olumsuz yönde etkilemektedir (Ameen ve ark., 2016; Bi ve ark., 2016; Chen \& Park, 2018). Özellikle yüksek nem tutma özelliği ile bilinen Li-TFSI katkısı havadaki nemi emerek hareketli Li iyonları sayesinde doğrudan perovskit tabakasının içine doğru penetre olur ve böylece neme karşı yüksek duyarlılığa sahip perovskit tabakasının bozunumunu hızlandırır (X. Huang ve ark., 2019; Lai ve ark., 2019). Benzer şekilde tBP katkısı da operasyonel koşullarda $\left[\mathrm{PbI}_{2} \cdot \mathrm{tBP}\right]$ kompleks yapısını oluşturarak hücre performansının kötüleşmesine sebep olmaktadır. Bir diğer aşılması gereken engel de özellikle operasyonel koşullarda spiro-OMeTAD malzemesinin kristallenerek hücre performansını olumsuz yönde etkilemesidir (Aitola ve ark., 2017).

Hücrenin nem ve termal kararlılığını etkileyen bu sorunların çözülmesi amacıyla çeşitli yöntemler geliştirilmiştir. Bu yöntemlerden biri de alternatif HTL malzemelerinin perovskit hücrelerde test edilmesidir. Bu yaklaşım doğrultusunda sayısız organik ve inorganik tabanlı malzeme hücre mimarisinde kullanılarak spiro-OMeTAD malzemesinin sunduğu verim değerinden ödün verilmeden mevcut problemlerin çözülmesi amaçlanmıştır. Ancak elde edilen bulgular göstermiştir ki; yalnızca sınırlı sayıda malzeme spiro-OMeTAD malzemesinin sunduğu verim değeri ile kıyaslanabilir bir verim değeri sunmaktadır. Diğer taraftan spiro-OMeTAD ile kıyaslanabilir verim sunan poly[bis(4-phenyl)-(3,5-dimethylphenyl)amine] (PTAA) (Yang ve ark., 2017) ve $\mathrm{N}^{2}, \mathrm{~N}^{2}, \mathrm{~N}^{7}, \mathrm{~N}^{7}$-tetrakis(9,9-dimethyl-9Hfluoren-2-yl)- $\mathrm{N}^{2}, \mathrm{~N}^{2}, \mathrm{~N}^{7}, \mathrm{~N}^{7^{\prime}}$-tetrakis(4-methoxyphenyl)-9,9'-spirobi[fluorene]-2,2',7,7'-tetraamine (DM) (Jeon ve ark., 2018) gibi organik tabanlı HTL malzemelerinin de düşük elektriksel parametreler sebebiyle katkılama ihtiyacı duyulması çalışmaların yönünü katkı malzemesi gerektirmeyen HTL malzemelerine çevirmiştir. Matsui v.d. tarafindan triarylamine-tabanlı polimerik malzemeler herhangi bir katkı malzemesi kullanılmadan perovskit hücre mimarisinde HTL malzemesi olarak test edilmiş ve \%12 verim değeri elde edilmiştir (Matsui ve ark., 2016). Ayrıca $85{ }^{\circ} \mathrm{C}$ sıcaklıkta 140 saat boyunca gerçekleştirilen termal kararlılık testlerinde de oldukça iyi bir kararlılık elde edildiği vurgulanmıştır. Bir başka çalışmada ise Zhang v.d. amonyum tabanlı X44 molekülünü sentezleyerek spiroOMeTAD malzemesine alternatif olarak perovskit hücrelerde kullanmışlardır (Zhang ve ark., 2017). Katkısız halde $9.03 \times 10^{-4} \mathrm{~S} \mathrm{~cm}^{-1}$ iletkenlik sunan X44 tabanlı hücrenin performansı \%15.2 olarak rapor edilirken bu değerin 15 gün sonunda \%16.2'ye ulaştı̆g bildirilmiştir. Operasyonel koşullarda da başlangıç verim değerinin \%90'ını koruduğu belirlenen X44 malzemesinin >\%50 nemli ve yüksek sıcaklık değerlerinde (60 ${ }^{\circ} \mathrm{C}$ 'ye kadar) gerçekleştirilen ölçüm sonuçları da başarılı sonuçlar vermiştir. Bu anlamda katkı gerektirmeyen ve yüksek iletkenlik/mobilite sunan inorganik tabanlı HTL malzemeleri büyük bir potansiyel sunsa da bu malzemelerin inorganik doğasından ve perovskit/HTL ve HTL/metal üst kontak arayüzeylerinde meydana gelen yoğun arayüzey durumları nedeniyle iyi verim değerlerine ulaşılamadığı bilinmektedir. Mevcut çalışmalardan da görüldüğü gibi kararlılık konusunda son derece iyi gelişmeler sağlansa da katkı içermeyen HTL tabanlı hücrelerin performansı bu hücre türünün ticarileşme potansiyelini oldukça zayıflatmaktadır. Benzer bulgular herhangi bir HTL malzemesinin kullanılmadığı (HTL-free) hücre mimarisinde de karşımıza çıkmaktadır. Bu alanda son yıllarda iyi bir ilerleme sağlansa da etkin bir boşluk transferinin gerçekleştirilemediği bu mimaride rapor edilen verim değerleri ticarileşme hedefinden oldukça uzak kalmıştır (Abu Laban \& Etgar, 2013; Mei ve ark., 2014; Rong ve ark., 2015).

Şu ana kadar rapor edilen çalışmalar birlikte değerlendirildiğinde hiçbir HTL malzemesinin spiro-OMeTAD, PTAA, DM HTL malzemeleri kadar etkin bir yük transferi gerçekleştiremediği ve yüksek hücre performansı sunamadığı görülmektedir. Bu durumda hücre performansından ödün vermeden nem ve termal kararlılık problemine çözüm sunmak için yeni yöntemlere ihtiyaç duyulduğu görülmektedir. Bu noktada geliştirilen en önemli yöntemlerden biri de perovskit/HTL arasında bir arayüzey malzemesinin kullanımı olmuştur. Böylece hem spiro-OMeTAD malzemesinin hücre performansı üzerindeki üstünlüğü sürdürülebilecek hem de spiro-OMeTAD malzemesinin içerdiği katkı maddeleri sebebiyle ivmelenen hücre bozunumu giderilebilecektir. Bu konuda son yıllarda bir çok malzeme perovskit/HTL arayüzeyinde denenmiş ve oldukça iyi sonuçlar rapor edilmiştir. 2019 yılında Akin v.d. CsPb(Br,I) 3 kuantum noktacıkları (QDs) perovskit/spiro-OMeTAD arayüzeyinde kullanarak hem perovskit malzemesinin yüzey pasivasyonunu sağlayarak hücre verimini 
iyileştirmiş hem de iyon göçünü engelleyerek uzun dönem hücre kararlılı̆̆ına katkı sağlamışlardır (Akin ve ark., 2019). Gerek hücre veriminde gerekse hücre kararlılığında benzer bir iyileşme de Huang v.d. tarafından 2018 yılında rapor edilmiştir (L. B. Huang ve ark., 2018). Bu çalışmada thiophene türevi poly(3-hexylthiophene) (P3HT) malzemesi perovskit/spiro-OMeTAD arayüzeyini iyileştirmek amacı ile kullanılııs ve başarılı sonuçlar elde edilmiştir. Verim değerinin arayüzey malzemesinin kullanılması ile \%15 değerinden \%19 değerine arttığı rapor edilirken, hücrelerin foto-kararlılık ölçümlerinin de iyileştiği vurgulanmıştır.

Bu çalışmada ise literatürde ilk defa hidrofobik davranışı ile bilinen thiol türevi 1-phenyl-1H-tetrazole-5-thiol (PT-thiol) molekülleri perovkit/spiro-OMeTAD arasında arayüzey malzemesi olarak kullanılmış ve ilgili malzemenin hem hücre performansına hem de uzun dönem hücre kararlılığına etkisi incelenmiştir. Farklı konsantrasyon değerlerinde (1, 5, $10 \mathrm{ve} 20 \mathrm{mg} / \mathrm{ml}$ ) hazırlanan PT(thiol) molekülleri döndürerek kaplama yöntemi ile perovskit tabaka üzerine büyütülerek kullanılan bu çalışmada $10 \mathrm{mg} / \mathrm{ml}$ konsantrasyona sahip arayüzey malzeme varlığında \%19.5 verim değeri elde edilmiştir. Daha da önemlisi sürekli ışınım altında gerçekleştirilen operasyonel kararlılık testlerinde de oldukça başarılı sonuçlar elde edilmiştir. Elde edilen bulgular göz önünde bulundurulduğunda arayüzey malzeme kullanımının perovskit hücre performansını iyileştirmenin yanında iyi bir koyucu tabaka görevi de üstlenerek hücrenin bozunumunu önemli ölçüde geciktirdiği söylenebilir.

\section{Materyal ve Metot}

\subsection{Hücre Üretimi}

\subsubsection{Alttaşların Temizleme Işlemi}

Hücre üretiminde alttaş olarak $1.4 \mathrm{~cm}$ x $2.6 \mathrm{~cm}$ boyutlarında flor-katkılı kalay oksit (fluorine-doped tin oxide, FTO) kaplı camlar kullanılmıştır. Kullanım öncesinde alttaşlar deterjanlı su içerisinde $30 \mathrm{dk}$ boyunca ultrasonik olarak yıkanmıştır. Daha sonra de-iyonize su ile durulanan alttaşlar sırasıyla aseton ve etanol içerisinde $15^{\prime}$ 'er $\mathrm{dk}$ boyunca yine ultrasonikasyon işlemine maruz bırakılmıştır. Temizleme işlemi sonrasında azot gazı ile kurutulan alttaşlar organik kalıntıların ve izlerin yüzeyden tamamen uzaklaştırılması için 15 dk boyunca UV-O ${ }_{3}$ cihazında bekletilmiştir.

\subsubsection{Kompakt ve Mezoporoz $\mathrm{TiO}_{2}$ Çözeltilerinin Hazırlanması ve Kaplama Işlemi}

Titanyum diizopropoksit bis(asetilasetonat) başlangıç kimyasalının etanol içerisinde hacimce 1:9 oranında seyreltilmesiyle hazırlanan titanyum dioksit $\left(\mathrm{TiO}_{2}\right)$ çözeltisi püskürtme tekniği kullanılarak $450{ }^{\circ} \mathrm{C}$ sıcaklıkta $\sim 40 \mathrm{~nm}$ kalınlıkta olacak şekilde FTO alttaşların yüzeyine kaplanmıştır. Elde edilen kompakt $\mathrm{TiO}_{2}\left(\mathrm{c}-\mathrm{TiO}_{2}\right)$ tabakası püskürtme işlemi sonrası yaklaşık $20 \mathrm{dk}$ süre ile $4500^{\circ} \mathrm{C}$ sıcaklıkta tavlama işlemine bırakılmıştır. Oda sıcaklığına soğutulan c- $\mathrm{TiO}_{2}$ kaplı alttaşların yüzeylerine döndürerek kaplama tekniği ile mezoporoz $\mathrm{TiO}_{2}\left(\mathrm{mp}-\mathrm{TiO}_{2}\right)$ çözeltisi kaplanmış ve $450{ }^{\circ} \mathrm{C}$ sıcaklıkta $30 \mathrm{dk}$ süre ile yeniden tavlama işlemine maruz bırakılmıştır. Mezoporoz çözelti $\mathrm{TiO}_{2}$ pastanın etanol içerisinde ağırlıkça 1:6 oranında seyreltilmesiyle hazırlanmıştır.

\subsubsection{Perovskit Çözeltisinin Sentezi ve Kaplama Işslemi}

Başlangıç malzemesi olarak kullanılan metilamonyum iyodür (MAI) ve kurşun iyodür $\left(\mathrm{PbI}_{2}\right)$ kimyasalları hacimce 1:4 oranında dimetil sülfoksit / dimetilformamid içerisinde çözdürülerek 1.35 M konsantrasyona sahip tekli katyon metilamonyum kurşun iyodür $\left(\mathrm{MAPbI}_{3}\right)$ perovskit çözeltisi hazırlanmıştır. Perovskit tabakasının büyütme işleminde tek-adımlı büyütme tekniği tercih edilmiştir. Döndürerek kaplama tekniği ile $\mathrm{FTO} / \mathrm{c}-\mathrm{TiO}_{2} / \mathrm{mp}-\mathrm{TiO}_{2}$ yüzeyine büyütülen perovskit tabakasının hızlı bir şekilde kristallenmesini sağlanmak amacıyla döndürme işleminin bitimine $10 \mathrm{sn}$ kala klorobenzen (anti-çözücü) perovskit yüzeyine damlatılmıştır. Kaplama işlemi sonrasında ise perovskit kaplı filmler $100{ }^{\circ} \mathrm{C}$ sıcaklıkta $45 \mathrm{dk}$ süre ile tavlanarak siyah renkte perovskit filmin oluşumu tamamlanmıştır.

\subsubsection{Arayüzey Çözeltisinin Sentezi ve Kaplama Işlemi}

Arayüzey malzemesi olarak kullanılan PT(thiol) başlangıç kimyasalı farklı konsantrasyon değerlerinde (1, 5, 10 ve $20 \mathrm{mg} / \mathrm{ml}) 2$ propanol içerisinde çözdürülerek hazırlanmış ve döndürerek kaplama tekniği kullanılarak perovskit yüzeyine büyütülmüştür. Büyütme işlemi sonrası çözücünün yüzeyden uzaklaştırılması amacı ile $80^{\circ} \mathrm{C}$ 'de $5 \mathrm{dk}$ kurutma işlemi gerçekleştirilmiştir.

\subsubsection{Spiro-OMeTAD Çözeltisinin Sentezi ve Kaplama Işlemi}

Spiro-OMeTAD çözeltisi klorobenzen çözücüsünde Li-TFSI ve tBP katkı maddelerinin de eklenmesiyle hazırlanmıştır. SpiroOMeTAD:Li-TFSI:tBP konsantrasyonu molar olarak 1.0:0.5:3.3 oranında olacak şekilde hazırlanmıştır. Spiro-OMeTAD çözeltisi perovskit ya da perovskit/PT(thiol) filmlerin üzerine döndürerek kaplama tekniği ile kaplanmıştır.

\subsection{6. Üst Kontakların Metalizasyonu}

Son olarak altın $\mathrm{Au}$ ) metal üst kontakların kaplanması amacıyla filmler termal buharlaştırma ünitesine alınmıştır. Uygun bir maske yardımıyla metal üst kontaklar spiro-OMeTAD film yüzeyine $\sim 80 \mathrm{~nm}$ kalınlıkta olacak şekilde buharlaştırılmıştır.

\subsection{Karakterizasyon Teknikleri}

\subsection{1. Üretilen Filmlerin Karakterizasyonu}


Üretilen perovskit filmlerin kristal yapıları Bruker D8 Advance model difraktometre ile analiz edilmiştir. Üretilen perovskit filmin optik soğurum spektrumları Varian CARY-500 model spektrofotometre ile incelenmiştir. Arayüzey içeren/içermeyen perovskit tabakaların morfolojik analizleri Zeiss marka taramalı elektron mikroskobu (SEM) ile karakterize edilmiştir. Perovskit ve perovskit/PT(thiol) yüzeylerinin hidrofobik davranışı Krüss DSA100 cihazı yardımıyla temas açısı ölçümü ile ölçülmüştür. Kullanılan PT(thiol) arayüzeyinin perovskit/HTL arayüzeyinde meydana gelen yük transferine ve rekombinasyon kinetiğine etkisi Fluorolog 322 model spektroflorometre ile analiz edilmiştir.

\subsection{2. Üretilen Hücrelerin Karakterizasyonu}

Hücrelerin akım-voltaj (I-V) karakteristikleri oda sıcaklığında ve dış ortamda ölçülmüştür. Hücreye ışık altında herhangi bir önkoşullandırma olmaksızın bir dış gerilim uygulanırken, üretilen fotoakım Keithley 2400 model sistem ile $50 \mathrm{mV} / \mathrm{s}$ tarama hızında kaydedilmiştir. Işık kaynağı olarak $450 \mathrm{~W}$ gücünde Xenon lamba (Oriel) kullanılmıştır. Hücreler, yanlardan ışık saçılmasını önlemek ve aktif alanı belirlemek amacıyla açıklık alanı, $0.16 \mathrm{~cm}^{2}$ olan ve yansıtıcı olmayan siyah metal bir maske ile kapatılmıştır. Güneş hücrelerinin IPCE (Incident photon to current efficiency) spektrumlar1 $300 \mathrm{~W}$ Xenon lambaya sahip Aekeo-Ariadne model cihaz ile kaydedilmiştir. Hücrelerin operasyonel kararlılık testleri Biologic MPG2 potansiyostatl $100 \mathrm{mWcm}^{-2}$ ş̧ık şiddeti yoğunluğuna sahip beyaz ışık yayan diyot lamba altında, özel olarak tasarlanmış numune tutucular yardımıyla $\sim \% 40$ bağıl neme sahip azot ortamında ölçülmüştür.

\section{Araştırma Sonuçları ve Tartışma}

$\mathrm{Bu}$ çalışmada kolay bir üretim süreci sunması bakımından tekli katyon perovskit $\left(\mathrm{MAPbI}_{3}\right)$ yapısı kullanılmıştır. Öncelikle üretilen perovskit filmlerin yapısal ve optik özellikleri analiz edilerek perovskit malzemesinin istenilen kalitede elde edilip edilmediği kontrol edilmiştir. Üretilen perovskit filmlerin kristal kalitelerini incelemek amacı ile XRD analiz sonuçlarından faydalanılmıştır. Bu çalışma kapsamında üretilen perovskit filmine ait XRD deseni Şekil 1a'da verilmiştir. XRD deseni incelendiğinde provskit yapısının iyi bir şekilde kristallendiği ve alttaştan gelen $\mathrm{FTO}$ ve $\mathrm{TiO}_{2}$ piklerinin haricinde istenmeyen ikincil fazları içermediği tespit edilmiştir. XRD deseninde gözlemlenen tüm pikler perovskit kristal yapısına ait olup; literatürde rapor edilen değerler ile uyum içindedir (Hoque ve ark., 2016; Quarti ve ark., 2016).
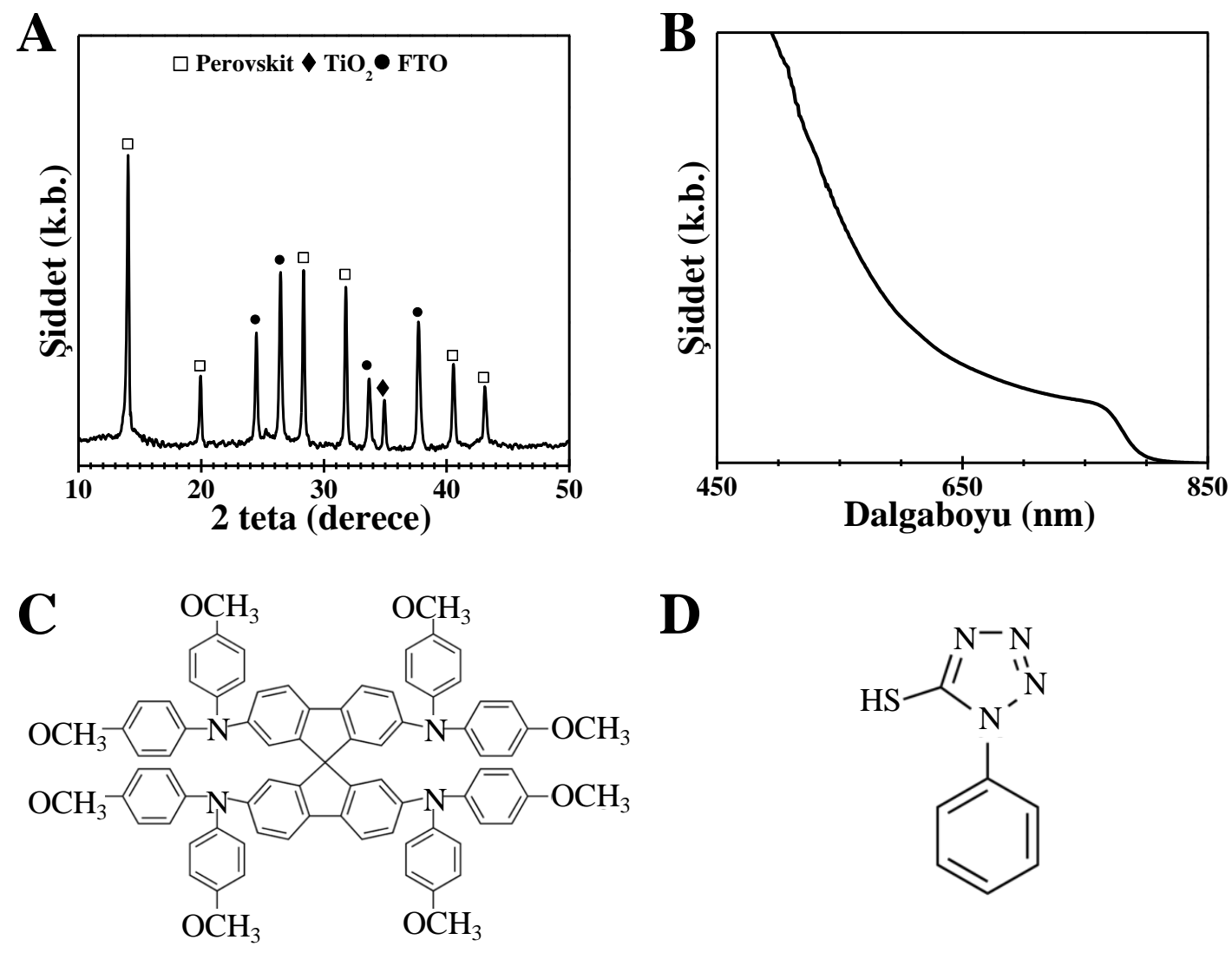

Şekil 1. (a) Üretilen perovskit filmine ait XRD deseni (b) Perovskit filmine ait dalgaboyunun bir fonksiyonu olarak soğurum spektrumu (c) Spiro-OMeTAD molekülünün kimyasal yapısı (d) PT(thiol) molekülünün kimyasal yapısı

İyi bir kristalitenin yanısıra perovskit tabakasının geniş bir dalgaboyu aralığında yüksek soğurum sunması da hücre performansı açısından son derece önemlidir. Üretilen perovskit filmin soğurum spektrumu Şekil $1 \mathrm{~b}$ 'de verilmiştir. Elde edilen soğurum spektrumu incelendiğinde soğurum kenarının yaklaşık $790 \mathrm{~nm}(1.58 \mathrm{eV})$ olduğu görülmektedir. Bu değer literatürde rapor edilen benzer reçete ile üretilen perovskit filmlerin soğurum spektrumu ile sıkı bir uyum içindedir (Ma ve ark., 2019; Pazos-Outon ve ark., 2018). 
Yüksek performans sunan hücrelerde bir diğer önemli parametre de perovskit malzemesinin yüzey özellikleridir. Öyle ki, iğnedeliği içermeyen sıkı bir yüzey morfolojisi hem yük taşınımında olası kayıpları engeleyecek hem de tabakalar arasında oluşabilecek kısa devre problemini ortadan kaldıracaktır. Perovskit tabakası ile ilgili bu iki durum hücre içerisinde meydana gelen rekombinasyon mekanizmaları ile de yakından ilgilidir. Bir diğer ifade ile perovskit yüzeyinde veya tane sınırlarında meydana gelen tuzak durumları rekombinasyon merkezi gibi davranarak fotovoltaik performansı olumsuz yönde etileyecek potansiyele sahiptir. Üretilen perovskit filmine ait yüzey morfolojisi SEM görüntüleri ile analiz edilmiş ve Şekil 2a'da paylaşılmıştır. Üstten görünüm yüzey morfolojisi incelendiğinde perovskit yapısını oluşturan tanelerin 200-300 nm aralığında uniform bir şekilde büyüdüğü görülmektedir. Ancak tane sınırlarında yer yer boşlukların ve derin yarıkların varlığı da dikkati çekmektedir. Bu boşluklar ve yarıklar operasyonel koşullarda rekombinasyon merkezi gibi davranarak hücre performansını düşürmektedir. Çünkü, bu tuzak durumları hücre içerisinde gerek spiroOMeTAD (Şekil 1c) malzemesindeki Li iyonlarının gerekse metal üst kontaktaki Au iyonlarının perovskit tabakasına doğru göçüne ve akım kaçaklarına neden olarak hücre kararlılığını ciddi oranda düşürmektedir (Akin ve ark., 2019; Akin, Liu, ve ark., 2018; Vidal ve ark., 2019).

$\mathrm{Bu}$ çalışmada perovskit yüzeyinde bulunan tuzak seviyelerinin pasivize edilerek hücre veriminin iyileştirilmesi ve aynı zamanda Li ve/veya Au iyonlarının perovskit tabaka içerisine penetre olmasını engelleyerek uzun dönem hücre kararlılığını iyileştirmek amacıyla PT(thiol) (Şekil 1d) arayüzeyi perovskit tabaka üzerine büyütülmüştür. Şekil 2b'de verilen PT(thiol) arayüzeyi içeren perovskit filmin SEM görüntüsü incelendiğinde de açık bir şekilde görüldüğü gibi arayüzey malzemesi provskit film yüzeyindeki tane sınırlarını ve derin yarıkları iyi bir şekilde doldurarak pasivize etmektedir. Bu durum tane sınırlarında meydana gelen elektronik kayıpları minimize ederek fotovoltaik performans açısından son derece önemli bir potansiyel sunmaktadır. Ayrıca düşük tuzak konsantrasyonuna sahip PT(thiol) arayüzeyi içeren perovskit filmin operasyonel koşullarda olası kaçak akım ve/veya kısa devre problemlerini de önemli bir oranda azaltma potansiyeli mevcuttur. Mevcut yüzey görüntüsünden de anlaşıldığı gibi arayüzey kaplama kalınlığı oldukça ince bir tabaka olup; SSekil 2c'de verilen tüm hücrenin kesit alan SEM görüntüsü ile de bu durum desteklenmektedir. İlgili kesit alan SEM görüntüsünden tüm tabakaların birbirleriyle iyi bir bağlantı kurduğu da söylenebilir.
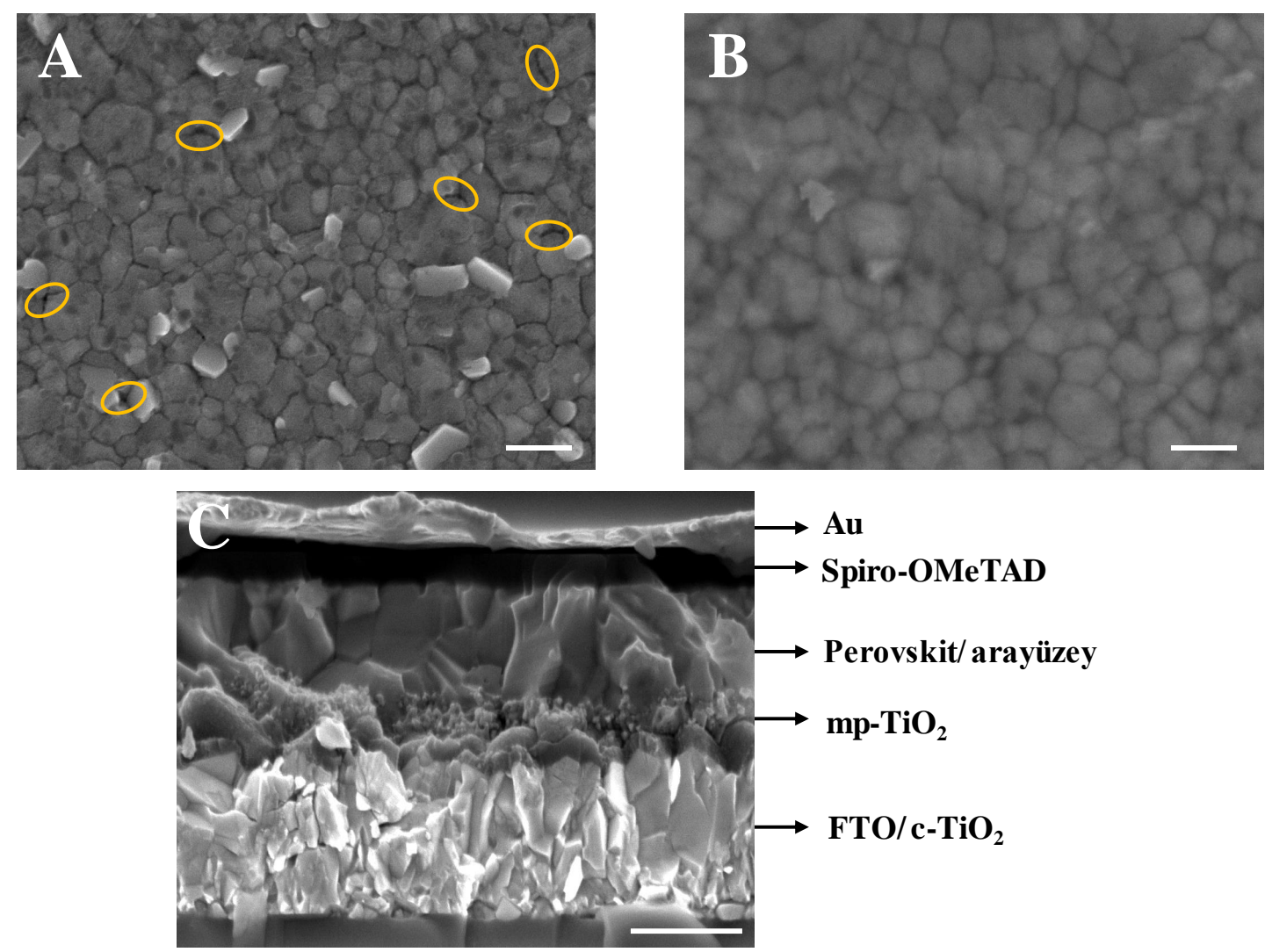

Şekil 2. (a) Üretilen perovskit filmin üstten SEM görüntüsü (b) Perovskit filmin arayüzey tabakanın varllğında üstten SEM görüntüsü (c) Arayüzey tabaka kullanılan hücrenin kesit alan SEM görüntüsü (ölçek: $500 \mathrm{~nm}$ )

Kullanılan PT(thiol) arayüzey malzemesinin hücre performansı üzerindeki etkisini incelemek amacıyla güneş hücreleri üretilmiş ve fotovoltaik karakterizasyonları gerçekleştirilmiştir. Arayüzey çalışmalarında dikkate alınması gereken en önemli parametrelerden biri arayüzey malzemesinin konsantrasyon değeridir. Optimum arayüzey malzeme konsantrasyonunu belirlemek amaciyla farklı konsantrasyon değerlerinde $(1,5,10$ ve $20 \mathrm{mg} / \mathrm{mL})$ hazırlanan arayüzey malzemesi perovskit yüzeyine büyütülerek fotovoltaik parametrelerin değişimi analiz edilmiştir. Her konsantrasyon değeri için 8 hücre üretilmiş ve konsantrasyona bağlı ortalama verim değişimi Şekil 3a'da paylaşılmıştır. $1 \mathrm{mg} / \mathrm{ml}$ konsantrasyonda hazırlanan arayüzey malzemesinin hücre performansını kısmen 
iyileştirdiği görülürken; 5 ve $10 \mathrm{mg} / \mathrm{ml}$ konsantrasyonlarda belirgin bir verim artışı olduğu dikkati çekmektedir. Konsantrasyon değeri $20 \mathrm{mg} / \mathrm{ml}$ değerine çıktığında ise arayüzey kalınlığına bağlı olarak yük transferinin zayıfladığı 1 ve hücre performansının düsştüğü görülmektedir. Mevcut ön-çalışma analiz sonuçları doğrultusunda $10 \mathrm{mg} / \mathrm{ml}$ konsantrasyon değerinin hücre üretimi için en uygun değer olduğu tespit edilmiştir.

Optimum konsantrasyon değerinde en iyi performasa sahip hücrelerin Şekil 3b'de sunulan J-V eğrisinden PT(thiol) arayüzey malzemesinin yap içerisine dahil edilmesi ile özellikle $\mathrm{FF}$ ve $\mathrm{V}_{\mathrm{OC}}$ değerlerinin iyileştiği bunun da hücre verimini iyileştirdiği sonucuna varılmıştır (Tablo 1). Arayüzey varlığında \%19.5 verim elde edilen bu çalışmada en iyi performansı gösteren kontrol hücresinin verim değeri ise \%18.1 olarak hesaplanmıştır. FF ve $\mathrm{V}_{\text {OC }}$ değerlerindeki iyileşmelerden kaynaklanan bu verim artışı perovskit tabakasının yüzey özelliklerinin iyileştirilerek hücre içerisindeki elektron-boşluk çiftlerinin rekombinasyon oranını düşürmesine atfedilebilir (Kim ve ark., 2019; Sherkar ve ark., 2017; Tress ve ark., 2018). Diğer taraftan arayüzey varlığında hücrenin J $\mathrm{JSC}_{\mathrm{SC}}$ değeri üzerinde herhangi kayda değer bir değişimin olmadığı da dikkati çekmektedir. J-V eğrilerinden elde edilen $\mathrm{J}_{\mathrm{SC}}$ değerleri $\left(\sim 23.1 \mathrm{~mA} / \mathrm{cm}^{2}\right)$ IPCE spektrumu aracılığı ile de test edilerek desteklenmiştir (Şekil 3c). Benzer $\mathrm{J}_{\mathrm{SC}}$ değerlerinin bir sonucu olarak da hücrelerin geniş bir bölgede iyi bir kuantum verimlilik ( $>\% 85$ üzerinde) sunduğu ve spektrumların benzer bir trend sergilediği görülmektedir. Bu durum kullanılan PT(thiol) arayüzey kalınlığının perovskit soğurucu tabakasının soğurum özellikleri üzerinde önemli bir etkisinin olmadığı anlamına gelmektedir.

A
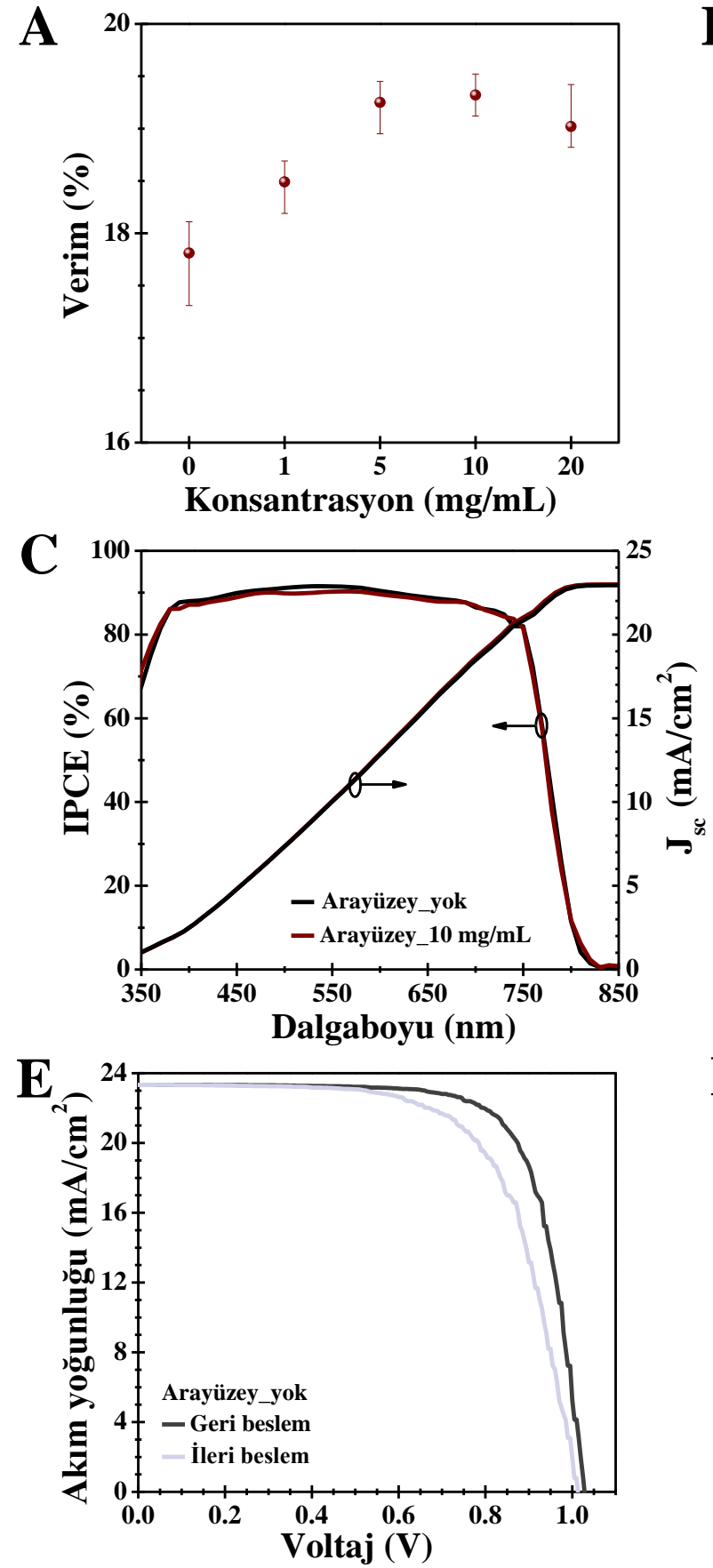

B

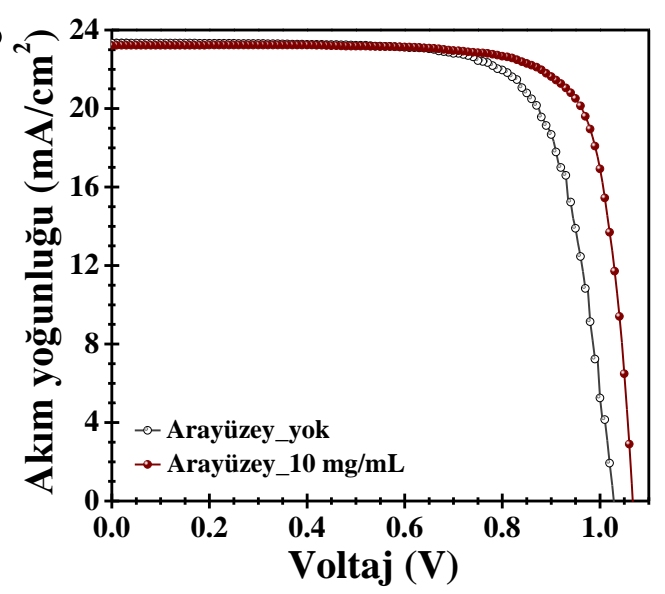

D

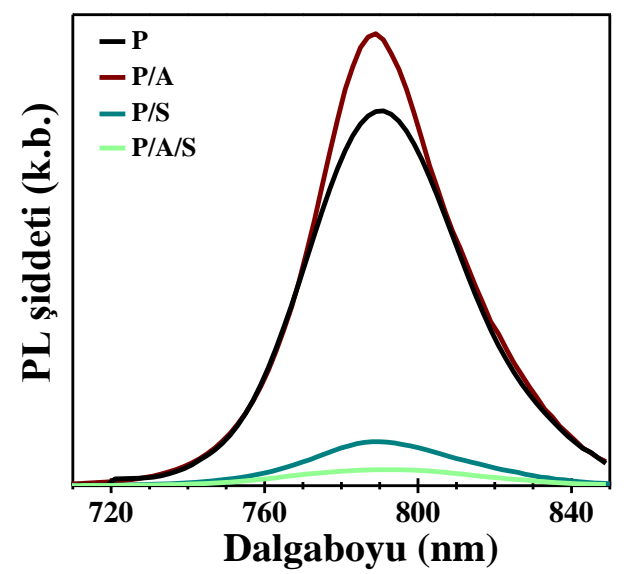

$\mathbf{F}$

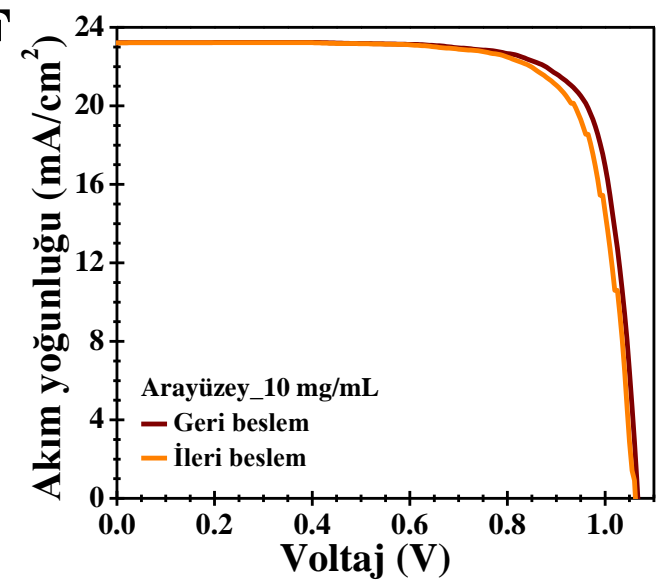

Şekil 3. (a) Arayüzey malzemesinin konsantrasyonuna bağlı olarak elde edilen ortalama hücre verimleri (b) En iyi performansa sahip kontrol hücresinin ve arayüzey içeren hücrenin J-V eğrileri (c) Illgili hücrelerin IPCE spektrumlart ve integre $J_{S C}$ değerleri (d) 
Arayüzey içeren ve içermeyen perovskit filmlerin PL spektrumları (P: perovskit, A: arayüzey, S: spiro-OMeTAD) (e) Kontrol hücresinin ileri beslem ve geri beslem J-V ĕgrisi (f) Arayüzey içeren hücrenin ileri beslem ve geri beslem J-V ĕgrisi

Fotovoltaik parametrelerdeki değişimi daha ayrıntılı olarak inceleyebilmek amacıyla arayüzey içeren/içermeyen perovskit filmlerin spiro-OMeTAD varlığında/yokluğunda PL analizleri gerçekleştirilmiştir. Şekil 3d'de verilen PL analizi dikkate alındığında tüm perovskit filmlerin $790 \mathrm{~nm}$ civarında bir pik verdiği bunun da mevcut soğurum spektrumu ile uyum içerisinde olduğu görülmektedir. Arayüzey tabakanın kullanıldığı durumda perovskit filmin kaliteli yüzey özelliklerinin bir sonucu olarak daha yüksek bir pik şiddeti sunduğu görülmektedir. Spiro-OMeTAD tabakasının varlı̆̆ında ise arayüzey içeren filmin en düşük pik şiddetini verdiği görülmektedir. $\mathrm{Bu}$ durum ise arayüzey boyunca meydana gelen etkin taşıyıcı ekstraksiyonuna atfedilebilir (Akin, Ulusu, ve ark., 2018; Arora ve ark., 2017). Bilindiği gibi taşıyıcı ekstraksiyonu soğurucu tabakanın yüzey özellikleri ile yakından ilgili olup; kusur içermeyen ve sıkı taneli bir perovskit yüzeyi yük ekstraksiyonunu etkin bir şekilde gerçekleştirmek için gerekli şartlardan biridir.

Perovskit güneş hücrelerinin fotovoltaik performansları ölçüm parametrelerine sıkı bir şekilde bağlı olup; elde edilen verim değerlerinin beslem yönüne (ileri beslem, geri beslem) bağlı olarak da incelenmesi sonuçların güvenilirliği açısından son derece önemlidir. Histeresis etkisi olarak tanımlanan bu durum perovskit malzemesinin yüksek iyonik iletkenliğinden dolayı iyon göçüne neden olması ve/veya farklı yük akısına sahip perovskit/yük transfer tabakaları arayüzeylerindeki yük akümülasyonu ile açıklanabilir. Mevcut çalışmada kullanılan arayüzey malzemesinin histeresis etkisini incelemek amacıyla hücrelerin ileri ve geri beslem şartlarında $\mathrm{J}-\mathrm{V}$ analizleri gerçekleştirilmiştir. Şekil 3e ve 3f'de verilen J-V eğrileri incelendiğinde, histeresis etkisi PT(thiol) arayüzey içeren hücreler için ihmal edilir bir derecede iken ( $\% 0.6)$; kontrol hücresi için yaklaşık $\% 2.2$ verim farkına sebep olmaktadır. Bu durum PT(thiol) malzemesinin perovskit/spiro-OMeTAD arayüzey durumlarını azaltarak; arayüzeyde yük birikimine müsade etmemesine atfedilebilir.

Perovskit hücrelerin ticarileşmesinin önündeki bir diğer engel de uzun dönem kararlılık problemidir (Xiang ve ark., 2019). Bu çalışmada kullanılan arayüzey malzemesinin hücre kararlılığı üzerindeki etkisini incelemek amacıyla arayüzey içeren ve içermeyen hücrelerin operasyonel kararlılık testleri gerçekleştirilmiş ve sonuçlar Şekil 4a'da paylaşılmıştır. \%40 nem içeren azot ortamında ve sürekli ışınım altında gerçekleştirilen ölçüm sonuçları incelendiğinde arayüzey tabaka kullanılan hücrenin yaklaşık 300 saat sonunda başlangıç verim değerinin \%75'ini koruduğu görülürken; arayüzey kullanılmayan hücrenin yaklaşık 100 saat sonunda \%80 verim kaybettiği belirlenmiştir. Arayüzey tabakanın hücre kararlılığı üzerindeki koruyucu rolünü açıklamak amacıyla su temas açısı ölçümlerinden yararlanılmıştır. Şekil 4b'de verilen su temas açısı ölçümlerinden de açık bir şekilde görüldüğü gibi arayüzey tabakanın hidrofobik doğasından dolayı su moleküllerinin perovskit tabakaya penetre olmasını geciktirdiği böylece hücre kararlılığına katkı sağladığı görülmektedir. Bu durum thiol türevi malzemelerin sahip olduğu yüksek hidrofobik motifler $\left(\mathrm{HS}-\mathrm{C}_{6} \mathrm{~F}_{5}\right.$ gibi) ile açılanabilir (Cao ve ark., 2015). PH(thiol) tabakasının koruyucu rolü perovskit filmlerin $\% 50 \pm 5$ nem içeren dış ortamdaki zamana bağlı dijital görüntülerinden de açı bir şekilde görülmektedir (Şekil 4c). Ancak, spiro-OMeTAD tabakasından perovskit ve hatta $\mathrm{TiO}_{2}$ tabakasına doğru ilerleyerek hücre bozunumuna neden olan sadece nem faktörü olmayıp; zamanla üst metal elektrottan altın iyonlarının ve benzer şekilde spiro-OMeTAD içindeki Li iyonlarının operasyonel koşullarda perovskit tabakasına doğru ilerleyerek hücre verimini ve kararlılı̆ıını olumsuz etkilediği de bilinmektedir. Kullanılan arayüzey malzemesinin perovskit tabaka üzerinde bir bariyer gibi davranarak iyon göçünü engelleme potansiyeli de açıktır (Javaid ve ark., 2018; Qiu ve ark., 2017; Wu ve ark., 2019). Sonuç olarak hücre veriminde gösterdiği iyileşme ve kararlılık problemine yaptı̆̆ önemli katkılar sebebiyle arayüzey malzemelerin perovskit hücrelerin ticari bir boyut kazanabilmesi için ivmelendirici bir rolü olduğu söylenebilir. 


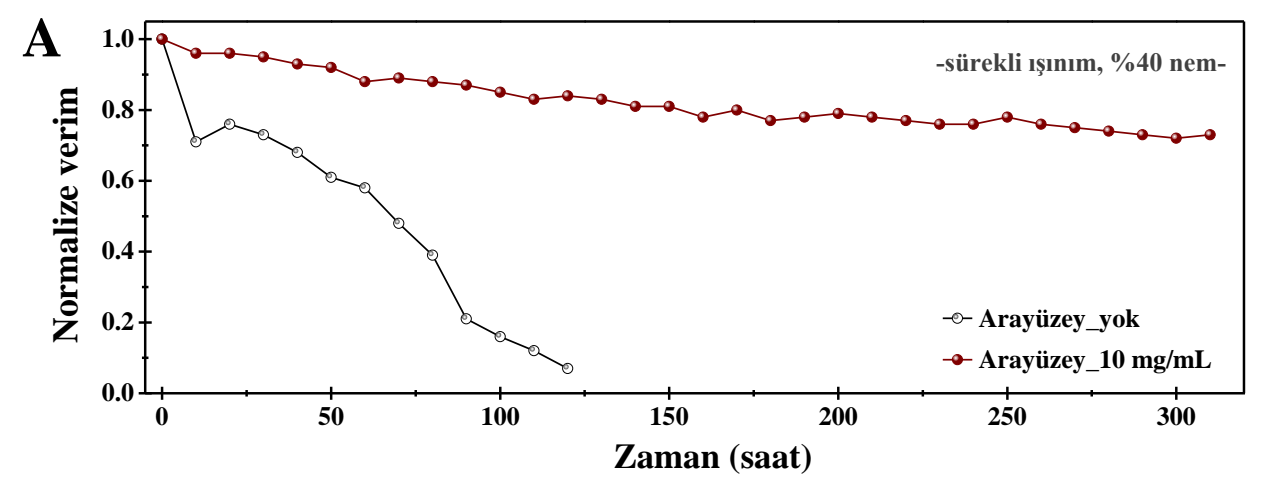

B

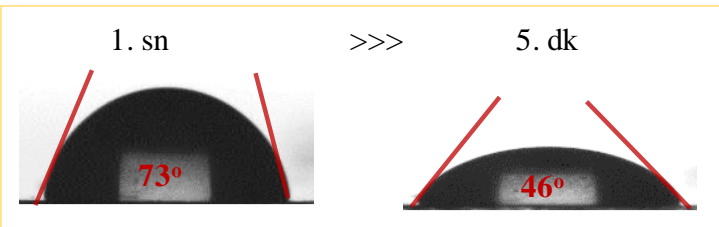

Arayüzey_yok

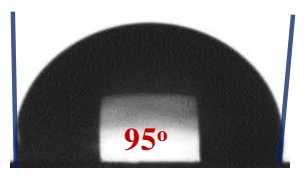

Arayüzey_10 mg/mL
C 1. gün $\gg>$ 5. gün

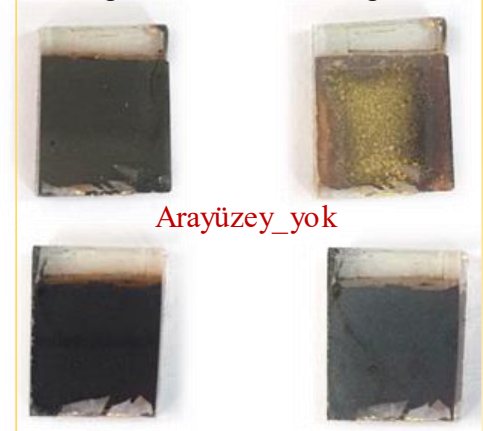

Arayüzey_10 mg/mL

Şekil 4. (a) Sürekli lşınım altında gerçekleştirilen operasyonel kararlıllk testleri (b) Arayüzey içeren ve içermeyen perovskit filmlerin zamana bağll su temas açısı ölçümleri (c) Arayüzey içeren ve içermeyen perovskit filmlerin \%50 \pm 5 nem içeren dlş ortamdaki zamana bağll dijital görüntüleri

Tablo 1. En İyi Performansı Sunan Hücrelere ait Fotovoltaik Parametreler

\begin{tabular}{ccccc}
\hline \hline Hücre & $\begin{array}{c}\mathbf{J}_{\text {sc }} \\
\left(\mathbf{m A} / \mathbf{c m}^{2}\right)\end{array}$ & $\begin{array}{c}\mathbf{V}_{\text {oc }} \\
(\mathbf{V})\end{array}$ & FF & $\begin{array}{c}\text { Verim } \\
(\boldsymbol{\%})\end{array}$ \\
\hline Arayüzey_yok & 23.4 & 1.03 & 0.75 & 18.1 \\
Arayüzey_10 $\mathrm{mg} / \mathrm{mL}$ & 23.3 & 1.07 & 0.78 & 19.5 \\
\hline
\end{tabular}

\section{Sonuç}

Bu çalışmada PT(thiol) malzemesi perovskit güneş hücre mimarisinde perovskit/spiro-OMeTAD arayüzeyinde aratabaka olarak kullanılarak hücre verimi ve kararlılı̆̆ 1 üzerindeki etkisi incelenmiştir. Arayüzey tabakasının tekli-katyon perovskit tabaka yüzeyindeki ve tane sınılarındaki rekombinasyon merkezlerini pasivize ederek rekombinasyon oranını düşürdüğü ve böylece hücre verimini yaklaşık $\% 8$ oranında - \%18.1 değerinden $\% 19.5$ değerine - iyileştirdiği tespit edilmiştir. Ayrıca mevcut arayüzeyin hücre mimarisinde bariyer gibi davrandığı ve operasyonel şartlarda hücre kararlılığına da ciddi bir katkı sunduğu tespit edilmiştir. Sonuç olarak perovskit hücrelerin mevcut sorunlarının giderilmesinde arayüzey mühendisliğinin önemli katkılar sunduğu görülmüş olup; uygun özelliklere sahip arayüzey malzemelerinin perovskit hücrelerin fotovoltaik endüstrisinde söz sahibi olması yolunda önemli bir katkı sağlaması mümkündür.

\section{Kaynakça}

Abu Laban, W., \& Etgar, L. (2013). Depleted hole conductor-free lead halide iodide heterojunction solar cells. Energy \& Environmental Science, 6(11), 3249-3253.

Aitola, K., Domanski, K., Correa-Baena, J. P., Sveinbjornsson, K., Saliba, M., Abate, A., . . Boschloo, G. (2017). High temperaturestable perovskite solar cell based on low-cost carbon nanotube hole contact. Advanced Materials, 29(17), 1606398.

Akin, S., Altintas, Y., Mutlugun, E., \& Sonmezoglu, S. (2019). Cesium-lead based inorganic perovskite quantum-dots as interfacial layer for highly stable perovskite solar cells with exceeding 21\% efficiency. Nano Energy, 60, 557-566. 
Akin, S., Liu, Y., Dar, M. I., Zakeeruddin, S. M., Gratzel, M., Turan, S., \& Sonmezoglu, S. (2018). Hydrothermally processed $\mathrm{CuCrO}_{2}$ nanoparticles as an inorganic hole transporting material for low-cost perovskite solar cells with superior stability. Journal of Materials Chemistry A, 6(41), 20327-20337.

Akin, S., Ulusu, Y., Waller, H., Lakey, J. H., \& Sonmezoglu, S. (2018). Insight into interface engineering at $\mathrm{TiO}_{2} /$ dye through molecularly functionalized Cafl biopolymer. Acs Sustainable Chemistry \& Engineering, 6(2), 1825-1836.

Ameen, S., Rub, M. A., Kosa, S. A., Alamry, K. A., Akhtar, M. S., Shin, H. S., . . Nazeeruddin, M. K. (2016). Perovskite solar cells: Influence of hole transporting materials on power conversion efficiency. Chemsuschem, 9(1), 10-27.

Arora, N., Dar, M. I., Hinderhofer, A., Pellet, N., Schreiber, F., Zakeeruddin, S. M., \& Gratzel, M. (2017). Perovskite solar cells with CuSCN hole extraction layers yield stabilized efficiencies greater than 20\%. Science, 358(6364), 768-771.

Bi, D. Q., Xu, B., Gao, P., Sun, L. C., Graetzel, M., \& Hagfeldt, A. (2016). Facile synthesized organic hole transporting material for perovskite solar cell with efficiency of 19.8\%. Nano Energy, 23, 138-144.

Cao, J., Yin, J., Yuan, S. F., Zhao, Y., Li, J., \& Zheng, N. F. (2015). Thiols as interfacial modifiers to enhance the performance and stability of perovskite solar cells. Nanoscale, 7(21), 9443-9447.

Chen, J. Z., \& Park, N. G. (2018). Inorganic Hole Transporting Materials for Stable and High Efficiency Perovskite Solar Cells. Journal of Physical Chemistry C, 122(25), 14039-14063.

Hoque, M. N. F., Islam, N., Li, Z., Ren, G. F., Zhu, K., \& Fan, Z. Y. (2016). Ionic and optical properties of methylammonium lead iodide perovskite across the tetragonal-cubic structural phase transition. Chemsuschem, 9(18), 2692-2698.

Huang, L. B., Su, P. Y., Liu, J. M., Huang, J. F., Chen, Y. F., Qin, S., . . Su, C. Y. (2018). Interface engineering of perovskite solar cells with multifunctional polymer interlayer toward improved performance and stability. Journal of Power Sources, 378, 483-490.

Huang, X., Bi, W. T., Jia, P. C., Tang, Y., Lou, Z. D., Hu, Y. F., . . Teng, F. (2019). Enhanced efficiency and light stability of planar perovskite solar cells by diethylammonium bromide induced large-grain 2D/3D hybrid film. Organic Electronics, 67, 101-108.

Javaid, S., Myung, C. W., Pourasad, S., Rakshit, B., Kim, K. S., \& Lee, G. (2018). A highly hydrophobic fluorographene-based system as an interlayer for electron transport in organic-inorganic perovskite solar cells. Journal of Materials Chemistry A, 6(38), $18635-18640$

Jeon, N. J., Na, H., Jung, E. H., Yang, T. Y., Lee, Y. G., Kim, G., . . Seo, J. (2018). A fluorene-terminated hole-transporting material for highly efficient and stable perovskite solar cells. Nature Energy, 3(8), 682-689.

Kim, H.-S., Seo, J.-Y., Akin, S., Simon, E., Fleischer, M., Zakeeruddin, S. M., . . Hagfeldt, A. (2019). Power output stabilizing feature in perovskite solar cells at operating condition: Selective contact-dependent charge recombination dynamics. Nano Energy, 61, 126-131.

Lai, H., Li, X., Li, S. P., Chen, Y., Sun, B. Y., Jiang, Q. H., \& Yang, J. Y. (2019). Enhancement of photovoltaic performance and moisture stability of perovskite solar cells by modification of tin phthalocyanine ( $\mathrm{SnPc})$. Electrochimica Acta, 296, 799-805.

Ma, Y. C., Hangoma, P. M., Park, W. I., Lim, J. H., Jung, Y. K., Jeong, J. H., . . Kim, K. H. (2019). Controlled crystal facet of MAPbI 3 perovskite for highly efficient and stable solar cell via nucleation modulation. Nanoscale, 11(1), 170-177.

Matsui, T., Petrikyte, I., Malinauskas, T., Domanski, K., Daskeviciene, M., Steponaitis, M., . . Saliba, M. (2016). Additive-free transparent triarylamine-based polymeric hole-transport materials for stable perovskite solar cells. Chemsuschem, 9(18), 2567 2571.

Mei, A. Y., Li, X., Liu, L. F., Ku, Z. L., Liu, T. F., Rong, Y. G., . . Han, H. W. (2014). A hole-conductor-free, fully printable mesoscopic perovskite solar cell with high stability. Science, 345(6194), 295-298.

National Renewable Energy Laboratory (NREL). (2019). Retrieved from https://www.nrel.gov/pv/cell-efficiency.html

Pazos-Outon, L. M., Xiao, T. P., \& Yablonovitch, E. (2018). Fundamental efficiency limit of lead iodide perovskite solar cells. Journal of Physical Chemistry Letters, 9(7), 1703-1711.

Qiu, W., Bastos, J. P., Dasgupta, S., Merckx, T., Cardinaletti, I., Jenart, M. V. C., . . Cheyns, D. (2017). Highly efficient perovskite solar cells with crosslinked PCBM interlayers. Journal of Materials Chemistry A, 5(6), 2466-2472.

Quarti, C., Mosconi, E., Ball, J. M., D'Innocenzo, V., Tao, C., Pathak, S., . . De Angelis, F. (2016). Structural and optical properties of methylammonium lead iodide across the tetragonal to cubic phase transition: implications for perovskite solar cells. Energy \& Environmental Science, 9(1), 155-163.

Rong, Y. G., Liu, L. F., Mei, A. Y., Li, X., \& Han, H. W. (2015). Beyond Efficiency: the Challenge of Stability in Mesoscopic Perovskite Solar Cells. Advanced Energy Materials, 5(20).

Seo, J.-Y., Kim, H.-S., Akin, S., Stojanovic, M., Simon, E., Fleischer, M., . . Grätzel, M. (2018). Novel p-dopant toward highly efficient and stable perovskite solar cells. Energy \& Environmental Science, 11(10), 2985-2992.

Sherkar, T. S., Momblona, C., Gil-Escrig, L., Avila, J., Sessolo, M., Bolink, H. J., \& Koster, L. J. A. (2017). Recombination in perovskite solar cells: Significance of grain boundaries, interface traps, and defect ions. Acs Energy Letters, 2(5), 1214-1222.

Tress, W., Yavari, M., Domanski, K., Yadav, P., Niesen, B., Baena, J. P. C., . . Graetzel, M. (2018). Interpretation and evolution of open-circuit voltage, recombination, ideality factor and subgap defect states during reversible light-soaking and irreversible degradation of perovskite solar cells (vol 11, pg 151, 2018). Energy \& Environmental Science, 11(3), 715-715.

Vidal, S., Izquierdo, M., Filippone, S., Fernandez, I., Akin, S., Seo, J. Y., . . Martin, N. (2019). Site-selective synthesis of -[70]PCBMlike fullerenes: Efficient application in perovskite solar cells. Chemistry-A European Journal, 25(13), 3224-3228.

Wu, S. H., Chen, R., Zhang, S. S., Babu, B. H., Yue, Y. F., Zhu, H. M., . . Chen, W. (2019). A chemically inert bismuth interlayer enhances long-term stability of inverted perovskite solar cells. Nature Communications, 10, 1161.

Xiang, W. C., Wang, Z. W., Kubicki, D. J., Tress, W., Luo, J. S., Prochowicz, D., . . . Hagfeldt, A. (2019). Europium-doped CsPbI ${ }_{2} B r$ for stable and highly efficient inorganic perovskite solar cells. Joule, 3(1), 205-214.

Yang, W. S., Park, B. W., Jung, E. H., Jeon, N. J., Kim, Y. C., Lee, D. U., . . Seok, S. I. (2017). Iodide management in formamidiniumlead-halide-based perovskite layers for efficient solar cells. Science, 356(6345), 1376-1379. 
Zhang, J. B., Xu, B., Yang, L., Mingorance, A., Ruan, C. Q., Hua, Y., . . Johansson, E. M. J. (2017). Incorporation of counter ions in organic molecules: New strategy in developing dopant-free hole transport materials for efficient mixed-ion perovskite solar cells. Advanced Energy Materials, 7(14), 1602736. 